\title{
PENGARUH IDENTITAS SOSIAL SEBAGAI PEGAWAI SENIOR, KARAKTERISTIK PEKERJAAN, DUKUNGAN SOSIAL, DAN KEJENUHAN PADA SIKAP PEGAWAI TENTANG PEKERJAAN DAN PENSIUN
}

\author{
Mamik Setiyonini \\ Kementerian Komunikasi dan Informatika
}

\begin{abstract}
The aim of this research is to investigate the relationship between perceived sosial identity as an older worker, job characteristic, social support and burnout and attitude towards retirement and work. A total of 400 questionnaires were collected from workers over the aged of 50, and they were working in Ministry of Communication and Information, Jakarta. Purposive sampling were used in this research. Stuctural Equation Model (SEM) analyses were performed to test the influence of social identity as an older worker, job characteristic, social support and burnout to attitude towards retirement and work. Age, gender, marital status and education were used as demographics variables.

The result show that identification with older worker was positively related to intergenerational competition, and negatifly related to career development, bridge employment, devaluation work dan intention to early retirement. Intergroup permeability was positively related to intention to early retirement. Job characteristic was positively related to career development, intergenerational competition, bridge employment, devaluation work, burnout and intention to early retirement. Social support was negatifly related to burnout, and burnout was positively related to intention to early retirement. Intergroup permeability was not related to career development, intergenerational competition, bridge employment and devaluation work because older worker in this research felt intergroup unpermeability. It means older workers in this study feel the ageism and burnout at their workplace.
\end{abstract}

Keywords: age discrimination, retirement, employee attitudes, older workers, work identity, burnout

\begin{abstract}
ABSTRAK
Tujuan dari penelitian ini adalah untuk meneliti hubungan antara persepsi tentang identitas sosial sebagai pegawai senior, karakteristik pekerjaan, dukungan sosial dan kejenuhan, dan sikap pada pekerjaan dan pensiun. Sebanyak 400 kuesioner diberikan pada pegawai senior yang berusia di atas 50 tahun di lingkungan Kementerian Komunikasi dan Informatika, Jakarta. Stuctural Equation Model (SEM) digunakan untuk menguji pengaruh identitas sosial sebagai pegawai senior, karakteristik pekerjaan, dukungan sosial dan kejenuhan, serta kejenuhan
\end{abstract}


pada keinginan untuk segera pensiun. Penelitian ini menggunakan variabel demografis, yaitu usia, jenis kelamin, status perkawinan dan tingkat pendidikan.

Hasil penelitian ini menunjukkan bahwa identifikasi pegawai senior berpengaruh positif pada persaingan antar generasi dan berpengaruh negatif pada pengembangan karir, transisi pegawai ke pensiun, devaluasi pekerjaan, dan keinginan untuk segera pensiun. Kesediaan untuk tidak mengelompok berpengaruh positif pada keinginan untuk segera pensiun. Karakteristik pekerjaan berpengaruh positif pada pengembangan karir, persaingan antar generasi, transisi pegawai ke pensiun, devaluasi pekerjaan, kejenuhan, dan keinginan untuk segera pensiun. Dukungan sosial berpengaruh negatif pada kejenuhan dan kejenuhan berpengaruh positif pada keinginan untuk segera pensiun. Itu berarti bahwa pegawai senior yang diteliti merasakan adanya ageism dan kejenuhan di tempat kerjanya.

Kata kunci: diskriminasi berdasar usia, pensiun, sikap pegawai, pegawai tua, identitas pekerjaan, kejenuhan

Pensiun merupakan hal yang pasti akan dihadapi semua pegawai, khususnya pegawai negeri sipil. Pendapat umum pegawai tentang pensiun adalah berkaitan dengan dua kondisi yaitu berubahnya waktu dari bekerja secara penuh atau full-time ke tidak bekerja sama sekali dan keluarnya pegawai dari dunia kerja. Pensiun juga dianggap sebagai berakhirnya karir pegawai. Kesiapan untuk menghadapi pensiun bagi masing-masing pegawai berbeda-beda.

Adanya anggapan bahwa pegawai senior yang mendekati batas usia pensiun cenderung memiliki kondisi kesehatan yang semakin menurun, kurang cerdas, kinerja dan produktivitas yang perlu dipertanyakan yaitu berkaitan dengan produktivitas yang menurun, kondisi kesehatan menurun, kapasitas fisik yang semakin rendah, tidak fleksibel dalam hubungan sosial antar pekerja terutama dengan pekerja yang lebih muda, dan kurang tertarik dengan pelatihanpelatihan pengembangan diri dan pekerjaan (Taylor and Walker, 1998 dalam Buyens, Dijk, Dewilde dan Vos, 2009). Akan tetapi, kondisi sebenarnya tidak selalu demikian, banyak hal-hal positif yang dapat diteladani dari pegawai senior, diantaranya berkaitan dengan loyalitas pada pekerjaan dan organisasi, lebih handal karena berpengalaman, dan kadang lebih bijak dan efisien dalam menyelesaikan pekerjaan (Nelson, 2002; Thoronton, 2002; Abrams et al, 2006 dalam Buyens, Dijk, Dewilde dan Vos, 2009).

Kebanyakan penelitian terdahulu lebih memberikan perhatian pada variabel personal dan organisasi yang mempengaruhi keputusan untuk segera pensiun dari pada factor sosial seperti representasi sosial mengenai usia. Asumsi mengenai pegawai senior diantaranya adalah memilki perilaku seperti mengelompok dan perasaan adanya penurunan identitas sosial. Dua hal tersebut menimbulkan kekhawatiran dalam diri mereka, sehingga akan mempengaruhi sikap mereka pada pekerjaan. Disamping itu, adanya fenomena kejenuhan yang seringkali dirasakan oleh pegawai yang mendekati batas usia pensiun juga memiliki hubungan dengan perhatian mereka tentang pensiun. Menurut Maslach and Jackson, 2001 dalam Henkens dan Leenders, 2010, kejenuhan adalah syndrome tentang kelelahan secara emosional, sinis, dan keinginan untuk bekerja secara tidak efektif 
atau dengan kata lain berkurangnya prestasi pegawai. Kejenuhan menyebabkan menurunnya produktifitas, tingginya tingkat kemangkiran pegawai, dan keinginan untuk mengerjakan hanya satu pekerjaan.

Peneitian ini mencoba menggabungkan dua model penelitian yaitu penelitian tentang pengaruh identitas sosial sebagai pegawai senior pada sikap tentang pekerjaan dan pensiun (Desmette and Gaillard, 2008) dan penelitian tentang pengaruh karakteristik pekerjaan dan dukungan sosial pada kejenuhan dan pengaruh kejenuhan pada keinginan untuk segera pensiun (Henkens and Leenders, 2010). Kedua penelitian tersebut dilakukan pada pegawai senior di perusahaan swasta, sedangkan penelitian ini dilakukan pada pegawai di instansi pemerintah. Hal ini dilakukan sebab peneliti ingin menguji apakah akan diperoleh hasil penelitian yang sama jika dilakukan pada pegawai di instansi pemerintah. Penggabungan dua penelitian ini dilakukan untuk mengetahui factor-faktor yang menyebabkan sikap pegawai senior pada pekerjaan dan pensiun, serta untuk mengtahui apakah terjadi fenomena kejenuhan pada pegawai senior di instansi pemerintah. Pada prinsipnya, penggabungan dua penelitian akan menghasilkan penelitian yang lebih kompleks dan untuk memudahkan intepretasi maka dilakukan modifikasi analisis data, dimana dua penelitian sebelumnya menggunakan regresi berganda, di penelitian ini menggunakan SEM (Structural EquationModel).

Berdasar pada latar belakang tersebut, maka tujuan penelitian ini adalah menguji pengaruh identitas sosial sebagai pegawai senior (yaitu identifikasi pegawai senior dan kesediaan untuk tidak mengelompok) dan karakteristik pekerjaan pada sikap pegawai tentang pekerjaan dan pensiun, menguji pengaruh karakteristik pekerjaan dan dukungan sosial pada kejenuhan, dan menguji pengaruh kejenuhan pada keinginan untuk segera pensiun.

\section{TELAAH PUSTAKA}

\section{Identitas sosial sebagai pegawai senior}

Teori identitas sosial memiliki dua asumsi dasar. Pertama, anggota kelompok sosial adalah bagian dari definisi pribadi individu. Kedua, individu perlu untuk meraih image pribadi yang positif. Saat kelompok mereka bubar, maka mereka merasa memiliki identitas sosial negative. Selanjutnya, untuk dapat memiliki identitas sosial yang positif mereka dapat melakukan strategi kognitif dan perilaku. Teori identitas sosial membedakan strategi menjadi dua, yaitu strategi yang bertujuan untuk menaikkan status individu (transisi dari stigmatisasi kelompok ke kelompok yang lebih istimewa) dan strategi kelompok yang memiliki tujuan meningkatkan status kelompok secara keseluruhan (termasuk tindakan kolektif/bersama). Identitas pegawai senior dalam penelitian ini tergambar dalam dua variabel yaitu identifikasi pegawai senior dan kesediaan untuk tidak mengelompok.

\section{Sikap pegawai senior berkaitan dengan pekerjaan dan pensiun}

Keinginan untuk segera pensiun diindikasikan secara jelas berkaitan dengan ketertarikan pegawai senior pada pekerjaan. Namun keinginan untuk melepaskan diri dari pekerjaan dikendalikan oleh tingkatan kondisi psikologis seseorang diantaranya penurunan tingkat ketertarikan pada pekerjaan disebabkan karena adanya stigmatisasi pada mereka. Selain itu, menurut Ekert dan DeViney (1993) dalam Buyens, Dijk dan Vos, 2009, factor psikologis seperti penurunan komitmen dan kepuasan kerja, ketidakpuasan dengan karir yang diraih, kegelisahan yang memicu keinginan untuk meninggalkan tempat kerja 
berpengaruh positif pada keputusan pensiun pegawai senior. Dalam penelitian ini, sikap pegawai tentang pekerjaan dan pensiun digambarkan dalam lima variabel yaitu pengembangan karir, persaingan antar generasi dan redefinisi usia, devaluasi pekerjaan, transisi peagwai ke pensiun dan keinginan untuk segera pensiun.

\section{Karakteristik pekerjaan}

Pandangan positif tentang pekerjaan akan menciptakan kenyamanan dalm bekerja bagi pegawai senior, sebab mereka akan terus bersemangat bekerja meskipun di usia yang tergolong tua. Salah satu factor yang mempengaruhi keputusan pegawai untuk pensiun adalah tingkat wewenang untuk pengambilan keputusan dalam pekerjaan yang dimiliki. Wewenang pegawai dalam pekerjaan merupakan wujud kemampuan dalam pengambilan keputusan tentang kapan dan bagaimana melaksanakan tugas dan pekerjaan dengan baik. (Friedmann dan Havighurst, 1977: Philipson and Smith, 2005, dalam Buyens, Dijk dan Vos 2009). Tekanan fisik dalam bekerja akan lebih dirasakan oleh pegawai senior dibanding pegawai yang lebih muda, hal ini disebabkan oleh menurunnya kondisi fisik dan kesehatan pegawai senior terkait usia. Berdasar penelitian yang dilakukan oleh Frone, 2002 dalam Desmette dan Gaillard, 2008, menyatakan bahwa lebih banyak terjadi konflik pekerjaan yang berpengaruh pada keluarga dibandingkan konflik keluarga yang berpengaruh pada pekerjaan. Namun baik konflik keluarga maupun pekerjaan menyebabkan menurunnya kesehatan fisik pegawai senior. Dan pada saat konflik keluarga dan konflik pekerjaan ini saling berhubungan, maka akan meningkatkan keinginan untuk segera pensiun.

\section{Dukungan sosial}

Salah satu factor yang mendorong terjadinya kejenuhan adalah kurangnya dukungan sosial. Dukungan sosial dari beberapa sumber seperti manajer, kolega, rekan kerja adalah factor yang mempengaruhi kemungkinan terjadinya kejenuhan. Hubungan pegawai dengan manajer yang baik dapat mengurangi kemungkinan terjadinya kejenuhan, contohnya manajer yang memberikan umpan balik tentang pekerjaan dan menawarkan pekerjaan yang menantang pada pegawai. (Schaufeli dan Bakker, 2007 dalam Henkens dan Leenders, 2010).

\section{Kejenuhan (Burnout)}

Kejenuhan adalah menurunnya kemampuan untuk menghadapi stress dan berhubungan dengan disfungsi kronis pada pekerjaan. Dengan kata lain kejenuhan adalah hasil dari kondisi stress kronis berkepanjangan dalam pekerjaan (Shirom, 2003). Penjelasan umum dan pengukuran paling valid tentang kejenuhan adalah menggunkan Maslach Buurnout Inventory (MBI), (Maslach and Jackson, 1981). MBI terdiri atas item-item pengukuran sekelompok gejala yang berhubungan dengan syndrome burnout, diantaranya : kelelahan emosional, depersonalisasi dan prestasi kerja (Shirom, 2003).

Hasil penelitian Desmette and Gaillard, pada tahun 2008 menunjukkan bahwa variable independen yaitu identifikasi pegawai senior berpengaruh positif pada variable dependen yaitu persaingan antar generasi dan redefinisi usia, dan berpengaruh negative pada pengembangan karir, transisi pegawai ke pensiun, devaluasi pekerjaan dan keinginan untuk segera pensiun. Kesediaan untuk tidak mengelompok berpengaruh positif pada pengembangan karir dan keinginan untuk segera pensiun serta berpengaruh negative pada persaingan antar generasi dan redefinisi usia, transisi pegawai ke pensiun dan devaluasi pekerjaan. Karakteristik pekerjaan berpegaruh positif pada pengembangan karir, persaingan antar 
generasi dan redefinisi usia, transisi pegawai ke pensiun, dan devaluasi pekerjaan. Penelitian ini menggunakan variable demografis usia, jenis kelamin, status pernikahan dan tingkat pendidikan. Berdasar pada penelitian di atas, maka dapat dirumuskan hipotesis sebagai berikut:

Hla. Identifikasi pegawai senior
berpengaruh negative pada
pengembangan karir

H1b. Kesediaan untuk tidak mengelompok berpengaruh positif pada pengembangan karir

H1c. Karakteristik berpengaruh positif pada pengembangan karir

H2a. Identifikasi pegawai senior berpengaruh positif pada persaingan antar generasi dan redefinisi usia

H2b. Kesediaan untuk tidak mengelompok berpengaruh negative pada persaingan antar generasi dan redefinisi usia

H2c. Karakteristik persaingan antar positif pada redefinisi usia

H3a. Identifikasi pegawai senior berpengaruh negative pada transisi dari pegawai ke pensiun

H3b. Kesediaan untuk

tidak mengelompok berpengaruh negative pada transisi dari pegawai ke pensiun

H3c. Karakteristik pekerjaan berpengaruh positif pada transisi pegawai ke pensiun

H4a. Identifikasi pegawai senior
berpengaruh negative pada
devaluasi pekerjaan
H4b. Kesediaan untuk tidak mengelompok berpengaruh negative pada devaluasi pekerjaan

H4c. Karakteristik pekerjaan berpengaruh positif pada devaluasi pekerjaan

H5a. Identifikasi pegawai senior berpengaruh negative pada keinginan untuk segera pensiun

H5b. Kesediaan untuk tidak mengelompok berpengaruh positif pada keinginan untuk segera pensiun

H5c. Karakteristik pekerjaan berpengaruh positif pada keinginan untuk segera pensiun

Penelitian yang dilakukan Henkens and Lenders, 2010 menghasilkan bahwa karakteristik pekerjaan dan dukungan sosial berpengaruh pada terjadinya kejenuhan, dan kejenuhan berpengaruh pada keinginan untuk segera pensiun. Karakteristik pekerjaan berpengaruh positif pada kejenuhan, dan dukungan sosial berpengaruh negative pada kejenuhan. Disamping itu juga dinyatakan bahwa ada hubungan positif antara kejenuhan dan keinginan untuk segera pensiun dengan asumsi bahwa kejenuhan akan berkurang setelah pensiun. Penelitian ini menggunakan variable demografis usia, jenis kelamin, status pernikahan dan tingkat pendidikan. Berdasar pada penelitian di atas, maka dapat dirumuskan hipotesis sebagai berikut:

H6. Karakteristik berpengaruh positif pada kejenuhan H7. Dukungan sosial berpengaruh negative pada kejenuhan

H8. Kejenuhan berpengaruh positif pada keinginan untuk segera pensiun 


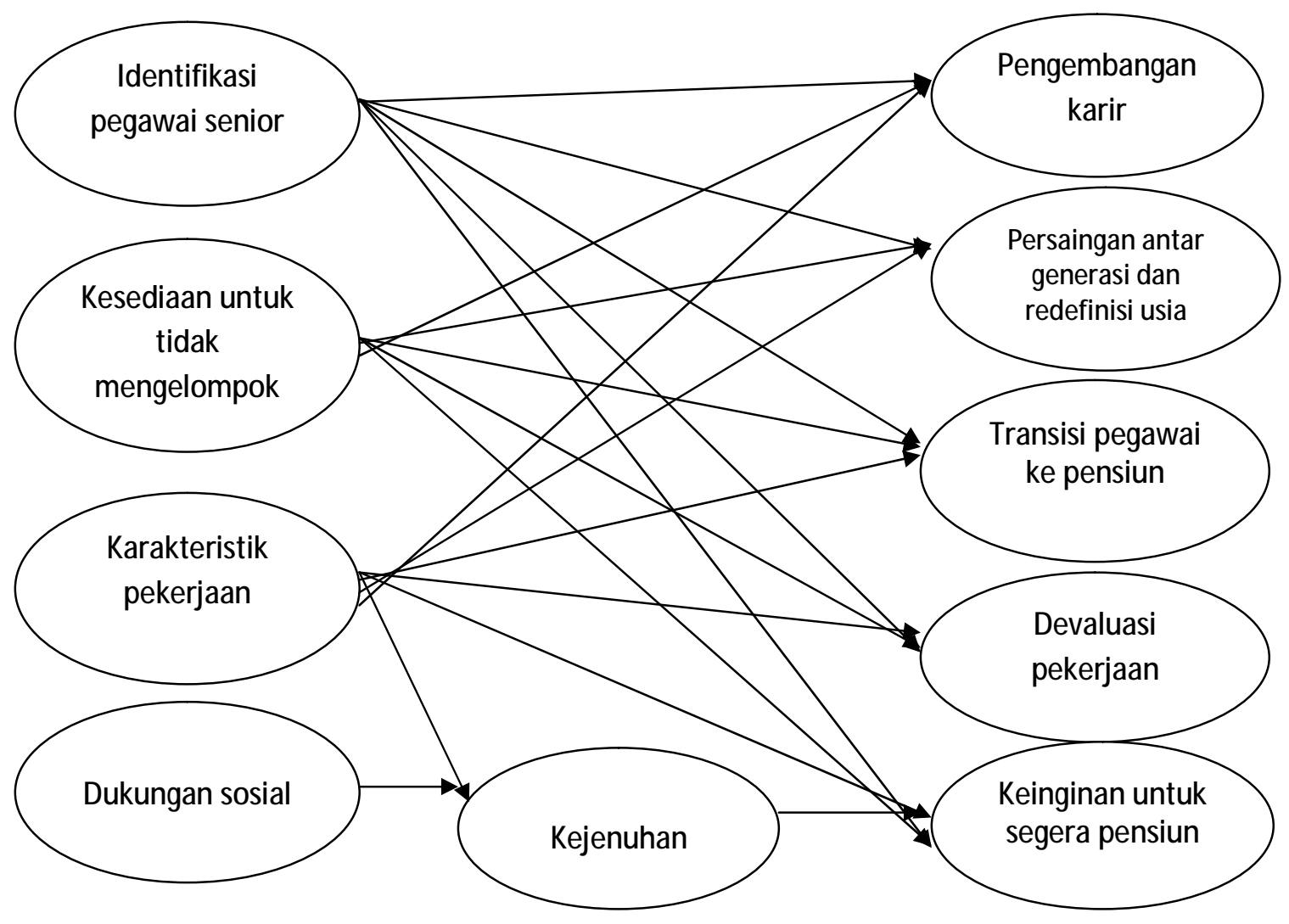

Gambar 1. Kerangka Pemikiran

\section{METODE PENELITIAN}

\section{Data}

Populasi dalam penelitian ini adalah seluruh pegawai Kementerian Komunikasi dan Informatika Jakarta.Sampel penelitian ini adalah seluruh pegawai Kementerian Komunikasi dan Informatika yang mendekati patas usia pensiun, yaitu berusia diatas 50 tahun. Teknik sampling yang digunakan dalam penelitian ini adalah purposive sampling yaitu dilakukan dengan mengambil sampel dari populasi berdasarkan pertimbangan (judgement) tertentu atau jatah (quota) tertentu (Jogiyanto, 2004). Kreteria sampel yang diambil yaitu semua pegawai kementerian Komunikasi dan Informatika yang berusia diatas 50 tahun.

\section{Definisi Operasional \\ Identitas sosial sebagai pegawai senior (older worker identity)}

Identitas sosial pegawai senior diukur dengan dua dimensi variable yaitu identifikasi pegawai senior dan kesediaan untuk tidak mengelompok. Identifikasi pegawai tua berkaitan dengan persepsi individual tentang "pegawai senior" atau identifikasi kognitif dan peran dalam kelompok atau identifikasi afektif. Identifikasi pegawai senior ini diukur dengan menggunakan empat item pertanyaan dalam kuesioner (Desmette, 2005). Kesediaan untuk tidak mengelompok adalah kesediaan pegawai senior untuk terbuka dengan lingkungan sosial, dalam hal ini pegawai lain baik yang mengelompok maupun tidak. Kesediaan untuk tidak 
mengelompok diukur dengan tiga item pertanyaan dalam kuesioner (Kessler and Mummendey : 2002 dalam Henkerns dan Leenders, 2010). Pengukuruannya menggunakan skala Likert jenjang 5 point.

\section{Karakteristik characteristic)}

pekerjaan

(job

Karakteristik pekerjaan adalah jenis pekerjaan yang dinilai memerlukan kondisi fisik yang kuat, kemampuan dalam menyelesaikan pekerjaan secara individu dan seberapa besar konflik dalam diri individu mempengaruhi pekerjaan yang dilakukan. Disamping itu karakteristik pekerjaan juga menggambarkan adanya tentangan dan peluang untuk berkembang dalam pekerjaan. Karakteristik pekerjaan diukur dengan tujuh item pertanyaan dalam kuesioner (Blekesaume and Solem : 2005 dan Halbesleben and Buckly : 2004 dalam Desmette dan Gailard, 2008). Pengukuran variabelnya dengan skala Likert jenjang 5 point.

\section{Dukungan sosial (social support)}

Dukungan sosial adalah adanya kondisi yang mendukung dilakukannya pekerjaan dengan maksimal, dukungan ini bisa berasal dari berbagai sumber yaitu atasan, kolega, rekan kerja dan bawahan. Dukungan sosial juga bisa berasal dari keluarga dan lingkungan soaial diluar pekerjaan. Adanya dukungan sosial yang kuat akan mempengaruhi kinerja pegawai senior dalam melakukan pekerjaannya. Dukungan sosial yang kurang menyebabkan terjadinya kejenuhan (Schaufeli and Baker : 2007 dalam Henkens dan Leenders, 2010). Dukungan sosial diukur dengan menggunakan tujuh belas item pertanyaan dalam kuesioner (Schaufeli and Bakker : 2007 dalam Henkens dan Leenders, 2010). Pengukuran variabelnya dengan skala Likert jenjang 5 point.

\section{Kejenuhan (Burnout)}

Kejenuhan adalah syndrome tentang kelelahan secara emosional, sinis, dan keinginan untuk bekerja secara tidak efektif atau dengan kata lain berkurangnya prestasi pegawai (Maslach and Jackson, 1981). Kejenuhan diukur dengan menggunakan dasar pengukuran Utrecht Burnout Scale (UBOS) dua belas item pertanyaan dalam kuesioner (Schaufeli and Van Dierendock : 2000 dalam Henkens dan Leenders, 2010). Pengukuran variabelnya dengan skala Likert jenjang 5 point.

\section{Pengembangan karir (career development)}

Pengembangan karir diukur dengan seberapa besar komitmen pegawai senior pada pekerjaannya. Komitmen pada pekerjaan ditunjukkan dengan pastisipasi aktif pegawai senior pada pekerjaannya, dengan berpatisipasi aktif pada pekerjaan maka akan lebih besar kemungkinan pegawai senior untuk dapat mengembangakan karirnya. Pengembangan karir diukur dengan menggunakan empat item pertanyaan dalam kuesioner. Pengukuran variabelnya dengan skala Likert jenjang 5 point.

\section{Persaingan anatar generasi dan redefinisi usia (intergenerationel competition and redefinition of ageing)}

Persaingan antar generasi adalah persaingan dalam pekerjaan yang terjadi antar pegawai senior dan rekan kerjanya yang lebih muda/junior. Redefinisi usia adalah kemampuan pegawai senior untuk dapat mengatasi stigmatisasi usia dalam pekerjaan. Persaingan antar generasi dan redefinisi usia diukur dengan menggunakan enam item pertanyaan dalam kuesioner (Mummendey : 1999). Pengukuran variabelnya dengan skala Likert jenjang 5 point. 
Ketertarikan pada pekerjaan dan pensiun (devaluation work, bridge employment, intention to early retirement)

Ketertarikan pada pekerjaan dan pensiun diukur dengan tiga dimensi variable, yaitu devaluasi pekerjaan, transisi pegawai ke pensiun dan keinginan untuk segera pensiun. devaluasi pekerjaan adalah hilangnya keterikatan psikologis pegawai senior pada pekerjaannya. Transisi pegawai ke pensiun adalah perilaku yang menggambarkan transisi pegawai saat memiliki status sebagai pegawai dan saat memiliki status pensiun, misalnya mengurangi jam kerja (transisi dari kerja full time ke tidak bekerja sama sekali). Keinginan untuk segera pensiun adalah perilaku yang dianggap sebagai gambaran dari perilaku pegawai yang bener-benar sudah pensiun (Hankens and Tazelaar : 1994, Schultz and Taylor : 2001 dalam Desmette dan Gaillard, 2008). Ketertarikan pada pekerjaan dan pensiun diukur dengan menggunakan tujuh item pertanyaan dalam kuesioner (Desmette, 2005). Pengukuran variabelnya dengan skala Likert jenjang 5 point.

\section{HASI L DAN PEM BAHASAN}

\section{Analisis Deskriptif}

Pada penelitian ini kuesioner yang disebarkan adalah sebanyak 400 kuesioner. Jumlah kuesioner yang bisa dikumpulkan kembali oleh peneliti adalah sejumlah 400 kuesioner (respon rate $100 \%$ ). Jumlah sampel data yang terkumpul telah memenuhi ukuran sampel minimum yang disyaratkan, yaitu 5 kali indikator yang digunakan (48 indikator) sehingga didapat sampel minimum sebesar 240 responden.

\section{Karakteristik Responden}

Gambaran umum tentang responden diperoleh dari data diri yang terdapat dalam kuesioner pada bagian identitas responden yang meliputi usia, jenis kelamin, status pernikahan dan tingkat pendidikan. Hasilnya menunjukkan bahwa rata-rata responden dalam penelitian ini memiliki usia rata-rata 51-53 tahun, jenis kelamin pria sebanyak 278 orang dan wanita 122 orang, tingkat pendidikan rata-rata SLTA, dan status pernikahan semuanya adalah menikah.

\section{Tanggapan Responden}

Hasil tanggapan responden pada masing-masing variabel adalah sebagai berikut $45 \%$ responden merasa memiliki keinginan untuk segera pensiun, 39,5\% responden berperilaku seperti pegawai yang sudah pensiun, $41 \%$ responden memiliki keterikatan psikologis dengan pekerjaannya, $51,81 \%$ responden merasa memiliki peluang untuk pengembangan karir dalam pekerjaannya, $47,67 \%$ responden merasa adanya persaingan antar generasi dan perlu untuk meredefinisi usianya saat bekerja, $42,68 \%$ responden merasa adanya karakteristik tertentu dalam pekerjaannya di tempat kerja, 56,25\% responden memiliki perilaku mengelompokdan tidak bersedia untuk terbuka dengan kelompok lain di tempat kerja, 38\% responden merasa memiliki identitas sebagai pegawai senior, $66,98 \%$ yang dapat diartikan bahwa responden merasakan kejenuhan dalam bekerja, dan $54,67 \%$ yang dapat diartikan bahwa responden merasa memiliki dukungan sosial di tempat kerja.

\section{Uji Validitas dan Uji Reliabilitas}

Hasil uji validitas untuk variabel independen dan dependen menunjukkan bahwa semua item pertanyaan yang digunakan adalah valid karena memiliki nilai loading factor $>0,50$. Dari hasil uji reliabilitas, nilai batas yang digunakan untuk menilai adalah sebuah tingkat reliabilitas yang dapat diterima adalah 0,7. Dengan demikian berdasarkan perhitungan, maka 
semua (sepuluh) variabel dinyatakan reliabel.

\section{Uji Asumsi Model \\ 1. Evaluasi Outliers}

Penelitian ini digunakan 48 variabel indikator, semua kasus yang mempunyai Jarak Mahalanobis lebih besar dari $\chi^{2}$ (48, $0.001)=86,072$ adalah multivariate outlier. Hasil evaluasi Jarak Mahalanobis menunjukkan bahwa ada outlier, karena ada observasi memiliki jarak mahalanobis > 86,072 . Sehingga data outlier tersebut harus dihilangkan dan dilakukan uji outlier yang ke dua. Dari hasil uji outlier ke dua sudah tidak lagi terdapat data outlier, sebab semua observasi memiliki jarak mahalanobis < 86,072 . Hal ini mengindikasikan bahwa tanggapan responden terhadap pernyataan dalam kuesioner relatif sama.

\section{Normalitas Data}

Hasil uji normalitas menandakan bahwa data dalam penelitian ini belum terdistribusi normal secara multivariate dengan nilai $C . r$ kurtosis 11,973. Meskipun data belum terdistribusi secara normal namun masih termasuk dalam kategori moderat sebab C.r kurtosisnya masih < 21 (Ghozali dan Fuad, 2005) sehingga analisis selanjutnya dilakukan.

\section{UJ HIPOTESIS}

1. Analisis Kesesuaian Model (Goodness-of-Fit) sesudah modifikasi

Tabel 1. Goodness of Fit

\begin{tabular}{|l|l|l|l|}
\hline Goodness of fit indices & Cut off Value & Hasil & Evaluasi Model \\
\hline Chi-Square $\left(\chi^{2}\right)$ & Diharapkan kecil & 1120.932 & $-\cdot-\cdot-\cdot----$ \\
\hline Significance Probability $(p)$ & $\geq 0,05$ & 0,10 & Baik \\
\hline CMIN/DF & $\leq 2,0$ & 1,107 & Baik \\
\hline GFI & $\geq 0,9$ & 0,900 & Marginal \\
\hline AGFI & $\geq 0,9$ & 0,883 & Marginal \\
\hline TLI & $\geq 0,9$ & 0,991 & Baik \\
\hline CFI & $\geq 0,9$ & 0,992 & Baik \\
\hline RMSEA & $\leq 0,08$ & 0,016 & baik \\
\hline
\end{tabular}

Sumber: Data primer yang diolah, 2012.

Setelah dilakukan modifikasi model, maka nilai CMIN/DF, TLI, CFI dan RMSEA dalam model penelitian ini menunjukkan tingkat kesesuaian yang baik.

\section{Analisis Koefisisen Jalur}

Tabel 2. Regression Weights

\begin{tabular}{|c|c|c|c|c|c|c|c|c|}
\hline & & & & Estimate & S.E. & C.R. & $\mathrm{P}$ & Label \\
\hline Kejenuhan & $<--$ & Dukungan soc & & -.252 & .045 & -5.598 & $* * *$ & \\
\hline Kejenuhan & $<---$ & Karakteristik & kerjaan & .071 & .022 & 3.268 & .001 & \\
\hline Pengembangan karir & $<---$ & $\begin{array}{l}\text { Identifikasi } \\
\text { senior }\end{array}$ & pegawai & -.100 & .038 & -2.618 & .009 & \\
\hline $\begin{array}{l}\text { Persaingan antar generasi } \\
\text { dan redefinisi }\end{array}$ & $<--$ & $\begin{array}{l}\text { Identifikasi } \\
\text { senior }\end{array}$ & pegawai & .121 & .048 & 2.543 & .011 & \\
\hline $\begin{array}{l}\text { Transisi pegawai ke } \\
\text { pensiun }\end{array}$ & $<--$ & $\begin{array}{l}\text { Identifikasi } \\
\text { senior }\end{array}$ & pegawai & -.100 & .051 & -1.970 & .049 & \\
\hline Devaluasi pekerjaan & $<--$ & $\begin{array}{l}\text { Identifikasi } \\
\text { senior }\end{array}$ & pegawai & -.261 & .049 & -5.293 & $* * *$ & \\
\hline Keinginan untuk & $<--$ & Identifikasi & pegawai & -.090 & .045 & -2.005 & .045 & \\
\hline
\end{tabular}


Jurnal Bisnis \& M anajemen

Vol. 14, N 0. 1, $2014: 47-62$

\begin{tabular}{|c|c|c|c|c|c|c|c|}
\hline & & & Estimate & S.E. & C.R. & $P$ & Label \\
\hline pensiun & & senior & & & & & \\
\hline Pengembangan karir & $<---$ & $\begin{array}{l}\text { Kesediaan untuk tidak } \\
\text { mengelompok }\end{array}$ & .025 & .051 & 494 & .621 & \\
\hline $\begin{array}{l}\text { Persaingan antar generasi } \\
\text { dan redefinisi }\end{array}$ & $<--$ & $\begin{array}{l}\text { Kesediaan untuk tidak } \\
\text { mengelompok }\end{array}$ & .037 & .063 & 579 & .562 & \\
\hline $\begin{array}{l}\text { Transisi pegawai ke } \\
\text { pensiun }\end{array}$ & $<--$ & $\begin{array}{l}\text { Kesediaan untuk tidak } \\
\text { mengelompok }\end{array}$ & .046 & .068 & .683 & .495 & \\
\hline Devaluasi pekerjaan & $<---$ & $\begin{array}{l}\text { Kesediaan untuk tidak } \\
\text { mengelompok }\end{array}$ & -.011 & .063 & -.177 & .860 & \\
\hline $\begin{array}{l}\text { Keinginan untuk segera } \\
\text { pensiun }\end{array}$ & $<--$ & $\begin{array}{l}\text { Kesediaan untuk tidak } \\
\text { mengelompok }\end{array}$ & .139 & .060 & 2.337 & .019 & \\
\hline Pengembangan karir & $<---$ & Karakteristik pekerjaan & .356 & .047 & 7.644 & $* * *$ & \\
\hline $\begin{array}{l}\text { Persaingan antar generasi } \\
\text { dan redefinisi }\end{array}$ & $<--$ & Karakteristik pekerjaan & 188 & .055 & 3.440 & $* * *$ & \\
\hline $\begin{array}{l}\text { Transisi pegawai ke } \\
\text { pensiun }\end{array}$ & $<--$ & Karakteristik pekerjaan & .330 & .059 & 5.561 & $* * *$ & \\
\hline Devaluasi pekerjaan & $<---$ & Karakteristik pekerjaan & 248 & .056 & 4.451 & $* * *$ & \\
\hline $\begin{array}{l}\text { Keinginan untuk segera } \\
\text { pensiun }\end{array}$ & $<--$ & Karakteristik pekerjaan & .385 & .054 & 7.078 & $* * *$ & \\
\hline $\begin{array}{l}\text { Keinginan untuk segera } \\
\text { pensiun }\end{array}$ & $<--$ & Kejenuhan & .326 & 107 & 3.034 & .002 & \\
\hline
\end{tabular}

Sumber: Data primer yang diolah, 2012 Keterangan : $\alpha=0.05$, *** bernilai 0.000

\section{Pembahasan}

Berdasar hasil pengujian dengan menggunakan SEM seperti tersaji dalam analisis, dan dapat dilihat dalam tabel 2 maka pembahasan dari hasil tersebut adalah sebagai berikut:

1. Hipotesis la yaitu "Identifikasi pegawai senior berpengaruh negatif pada pengembangan karir". C.R identifikasi pegawai senior pada pengembangan karir adalah sebesar 2,618 dengan tingkat signifikansi $p<0,05$, maka menunjukkan bahwa hipotesis la didukung. Artinya secara statistik dapat disimpulkan bahwa dalam penelitian ini identifikasi pegawai senior berpengaruh negatif pada pengembangan karir. Semakin pegawai menilai dirinya adalah pegawai senior maka akan semakin merasa karirnya tidak berkembang. Hasil penelitian ini mendukung penelitian yang dilakukan oleh Desmette dan Gaillard (2008).

2. Hipotesis $\mathbf{1 b}$ yaitu "Kesediaan untuk tidak mengelompok berpengaruh positif pada pengembangan karir". Nilai C.R. kesediaan untuk tidak mengelompok pada pengembangan karir adalah sebesar 0,494 dengan tingkat signifikansi $p>0,05$, maka menunjukkan bahwa hipotesis $\mathbf{1 b}$ tidak didukung. Artinya secara statistik dapat disimpulkan bahwa dalam penelitian ini kesediaan untuk tidak mengelompok tidak berpengaruh pada pengembangan karir. Meskipun pegawai senior merasa bersedia untuk tidak mengelompok dengan pegwai seusianya, akan tetapi tidak mempengaruhi pengembangan karir mereka dalam pekerjaan. Atau pagawai senior merasa bahwa pengembangan karir mereka tidak dipengaruhi oleh perilaku berkelompok dalam pekerjaan. 
Dalam penelitian ini pegawai senior cenderung mengelompok dan tidak bersedia untuk terbuka dengan kelompok lain.

3. Hipotesis 1c yaitu "Karakteristik pekerjaan berpengaruh positif pada pengembangan karir". Nilai C.R. karakteristik pekerjaan pada pengembangan karir adalah sebesar 7,644 dengan tingkat signifikansi $p<0,05$, maka menunjukkan bahwa hipotesis 1c didukung. Artinya secara statistik dapat disimpulkan bahwa dalam penelitian ini semakin pegawai senior merasa pekerjaannya memberikan tantangan dan peluang untuk berkembang maka pengembangan karirnya akan semakin baik. Semakin pegawai senior merasa bahwa karakteristik pekerjaannya sesuai dengan dirinya maka akan meningkatkan komitemennya pada pekerjaan yang pada akhirnya mempengaruhi pengembangan karirnya. Hasil penelitian ini mendukung penelitian sebelumnya yang dilakukan oleh Desmette dan Gaillard, 2008.

4. Hipotesis $2 a$ yaitu "Identifikasi pegawai senior berpengaruh positif pada persaingan antar generasi dan redefinisi usia". Nilai C.R. identifikasi pegawai senior pada persaingan antar generasi dan redefinisi usia adalah sebesar 2,543 dengan tingkat signifikansi $\mathrm{p}<0,05$, maka menunjukkan bahwa hipotesis $\mathbf{2 a}$ didukung. Artinya secara statistik dapat disimpulkan bahwa dalam penelitian ini semakin pegawai senior menilai dirinya adalah pegawai senior maka mereka merasa adanya persaingan antar generasi yang memungkinkan mereka melakukan redefinisi usia untuk mengatasi persaingan tersebut. Hasil penelitian ini mendukung penelitian sebelumnya yang dilakukan Desmette dan Gaillard (2008).
5. Hipotesis $2 \mathrm{~b}$ yaitu "Kesediaan untuk tidak mengelompok berpengaruh negatif pada persaingan antar generasi dan redefinisi usia". Nilai C.R kesediaan untuk tidak mengelompok pada persaingan antar generasi dan redefinisi usia adalah sebesar 0,579 dengan tingkat signifikansi $p>0,05$, maka menunjukkan bahwa hipotesis $\mathbf{2 b}$ tidak didukung. Artinya secara statistik dapat disimpulkan bahwa dalam penelitian ini perilaku kesediaan untuk tidak mengelompok pegawai senior tidak berpengaruh pada persaingan antar generasi dan redefinisi usia. Pegawai senior merasa bahwa berkelompok atau tidak dalam lingkungan pekerjaannya tidak mempengaruhi perasaan mereka tentang adanya persaingan antar generasi dan redefinisi usia. Dalam penelitian ini pegawai senior cenderung mengelompok dan tidak bersedia terbuka dengan kelompok lain.

6. Hipotesis 2c yaitu "Karakteristik pekerjaan berpengaruh positif pada persaingan antar generasi dan redefinisi usia". Nilai C.R karakteristik pekerjaan pada persaingan antar generasi dan redefinisi usia adalah sebesar 3,440 dengan tingkat signifikansi $p<0,05$, maka menunjukkan bahwa hipotesis 2c didukung. Artinya secara statistik dapat disimpulkan bahwa dalam penelitian ini karakteristik pekerjaan berpengaruh positif pada persaingan antar generasi dan redefinisi usia. Pegawai senior merasa bahwa semakin pekerjaannya memberikan tantangan dan peluang untuk berkembang maka semakin menyebabkan terjadinya persaingan antar generasi dan memungkinkan mereka untuk melakukan redefinisi usia untuk mengatasi persaingan tersebut. Hasil penelitian ini mendukung penelitian 
sebelumnya yang dilakukan oleh Desmette dan Gaillard, 2008.

7. Hipotesis $3 a$ yaitu "Identifikasi pegawai senior berpengaruh negatif pada transisi dari pegawai ke pensiun". Nilai C.R identifikasi pegawai senior pada transisi dari pegawai ke pensiun adalah sebesar $-1,970$ dengan tingkat signifikansi $p<0,05$, maka menunjukkan bahwa hipotesis $3 a$ didukung. Artinya secara statistik dapat disimpulkan bahwa dalam penelitian ini identifikasi pegawai senior berpengaruh negative pada transisi pegawai ke pensiun. Semakin pegawai senior merasa bahwa dirinya adalah pegawai senior, maka perilakunya semakin mendekati atau mirip dengan pegawai yang sudah pensiun, dan semakin berbeda dengan perilaku pegawai yang masih aktif bekerja, diantaranya adalah mereka cenderung mengurangi jam kerja yang merupakan transisi dari bekerja sesuai jam kerja ke tidak bekerja sama sekali. Hasil penelitian ini mendukung penelitian sebelumnya yang dilakukan oleh Desmette dan Gaillard, 2008.

8. Hipotesis 3b yaitu "Kesediaan untuk tidak mengelompok berpengaruh negatif pada transisi dari pegawai ke pensiun". Nilai C.R kesediaan untuk tidak mengelompok pada transisi dari pegawai ke pensiun adalah sebesar 0,683 dengan tingkat signifikansi $p>0,05$, maka menunjukkan bahwa hipotesis $3 \mathbf{b}$ tidak didukung. Artinya secara statistik dapat disimpulkan bahwa dalam penelitian ini kesediaan untuk tidak mengelompok tidak berpengaruh pada transisi dari pegawai ke pensiun. Meskipun pegawai senior bersedia untuk tidak mengelompok akan tetapi tidak mempengaruhi mereka untuk berperilaku seperti pegawai yang sudah pensiun. Dalam penelitian ini pegawai senior cenderung berkelompok dan tidak bersedia untuk terbuka dengan kelompok lain.

9. Hipotesis 3c yaitu "Karakteristik pekerjaan berpengaruh positif pada transisi dari pegawai ke pensiun". Nilai C.R karakteristik pekerjaan pada transisi dari pegawai ke pensiun adalah sebesar 5,561 dengan tingkat signifikansi $p<0,05$, maka menunjukkan bahwa hipotesis $3 c$ didukung. Artinya secara statistik dapat disimpulkan bahwa dalam penelitian ini semakin pekerjaan memberikan tantangan dan peluang untuk berkembang maka semakin mendorong pegawai senior untuk berperilaku seperti pegawai yang sudah pensiun. Pegawai senior merasa bahwa karakteristik pekerjaan yang tidak sesuai dengan dirinya akan menyebabkan mereka berperilaku seperti pegawai yang sudah pensiun. Hasil penelitian ini mendukung hasil penelitian sebelumnya yang dilakukan oleh Desmette dan Gaillard, 2008.

10. Hipotesis $4 a$ yaitu "Identifikasi pegawai senior berpengaruh negatif pada devaluasi pekerjaan". Nilai C.R identifikasi pegawai senior pada devaluasi pekerjaan adalah sebesar 5,293 , dengan tingkat signifikansi $p<0,05$, maka menunjukkan bahwa hipotesis $\mathbf{4 a}$ didukung. Artinya secara statistik dapat disimpulkan bahwa dalam penelitian ini semakin pegawai senior merasa bahwa dirinya adalah pegawai senior maka semakin merasa terikat secara psikologis dengan pekerjaannya. Pegawai senior rata-rata sudah bekerja dalam jangka waktu yang lama, sehingga mereka sudah merasa memiliki keterikatan psikologis dengan pekerjaannya. Ketika pegawai senior sadar akan statusnya sebagai pegawai senior maka akan sulit untuk melepaskan pekerjaannya yang sudah dijalaninya dalam jangka waktu yang lama. Hasil penlitian ini mendukung 
penelitian sebelumnya yang dilakukan oleh Desmette dan Gaillard, 2008.

11. Hipotesis $\mathbf{4 b}$ yaitu "Kesediaan untuk tidak mengelompok berpengaruh negatif pada devaluasi pekerjaan". Nilai C.R kesediaan untuk tidak mengelompok pada devaluasi pekerjaan adalah sebesar $-0,177$, dengan tingkat signifikansi $p>0,05$, maka menunjukkan bahwa hipotesis $\mathbf{4 b}$ tidak didukung. Artinya secara statistik dapat disimpulkan bahwa dalam penelitian ini kesediaan untuk tidak mengelompok tidak berpengaruh pada devaluasi pekerjaan. Pegawai senior merasa bahwa berkelompok atau tidak dalam lingkungan pekerjaannya tidak mempengaruhi keterikatan psikologis mereka pada pekerjaan. Dalam penelitian ini pegawai senior cenderung mengelompok dan tidak bersedia untuk terbuka dengan kelompok lain.

12. Hipotesis 4c yaitu "Karakteristik pekerjaan berpengaruh positif pada devaluasi pekerjaan". Nilai C.R karakteristik pekerjaan pada devaluasi pekerjaan adalah sebesar 4,451, dengan tingkat signifikansi $p<0,05$, maka menunjukkan bahwa hipotesis $4 \mathbf{4 c}$ didukung. Artinya secara statistik dapat disimpulkan bahwa dalam penelitian ini pegawai senior merasa semakin pekerjaannya memberikan tantangan dan peluang untuk berkembang maka semakin hilang keterikatan psikologis mereka dengan pekerjaan. Pegawai senior merasa bahwa tantangan dalam pekerjaan akan semakin berat bagi mereka dan peluang juga akan sulit untuk diraih. Hasil penelitian ini mendukung penelitian sebelumnya yang dilakukan oleh Desmette dan Gaillard, 2008.

13. Hipotesis 5a yaitu “identifikasi pegawai senior berpengaruh negative pada keinginan untuk segera pensiun". Nilai C.R identifikasi pegawai senior pada keinginan untuk segera pansiun adalah sebesar $-2,005$, dengan tingkat signifikansi $p<0,05$, maka menunjukkan bahwa hipotesis 5 a didukung. Artinya secara statistik dapat disimpulkan bahwa dalam penelitian ini semakin pegawai senior menyadari bahwa dirinya adalah pegawai senior maka semakin ingin untuk tetap bekerja atau tidak ingin segera pensiun. Ketika pegawai senior merasa dirinya adalah pegawai senior dan dapat menempatkan diri sebagai pegawai senior, maka akan merasa menikmati pekerjaannya, dan hal ini membuat mereka enggan untuk segera pensiun. Hasil penelitian ini mendukung penelitian sebelumnya yang dilakukan oleh Desmette dan Gaillard, 2008.

14. Hipotesis $5 b$ yaitu "Kesediaan untuk tidak mengelompok berpengaruh positif pada keinginan untuk segera pensiun". Nilai C.R kesediaan untuk tidak mengelompok pada keinginan untuk segera pensiun adalah sebesar 2,337, dengan tingkat signifikansi $p<0,05$, maka menunjukkan bahwa hipotesis $\mathbf{5 b}$ didukung. Artinya secara statistik dapat disimpulkan bahwa dalam penelitian ini semakin pegawai senior bersedia untuk tidak mengelompok maka semakin besar keinginan mereka untuk segera pensiun. Pegawai senior yang dapat beradaptasi dengan semua pegawai dari semua generasi akan merasa siap untuk meninggalkan lingkungan kerja dan masuk ke lingkungan di luar pekerjaan, bahkan mereka merasa dengan pensiun akan terbuka peluang untuk berkembang di luar tempat kerja. Hasil penelitian ini mendukung penelitian sebelumnya yang dilakukan oleh Desmette dan Gaillard, 2008.

15. Hipotesis 5c yaitu "Karakteristik pekerjaan berpengaruh positif pada keinginan untuk segera pensiun". 
Nilai C.R karakteristik pekerjaan pada keinginan untuk segera pensiun adalah sebesar 7,078 dengan tingkat signifikansi $\mathrm{p}<0,05$, maka menunjukkan bahwa hipotesis $\mathbf{5 c}$ didukung. Artinya secara statistik dapat disimpulkan bahwa dalam penelitian ini semakin pekerjaan memberikan tantangan dan peluang untuk berkembang bagi pegawai senior maka semakin tinggi keinginan mereka untuk segera pensiun. Pegawai senior merasa tidak lagi dapat menghadapi tantangan dan mengambil peluang dalam pekerjaannya, sehingga akan lebih memilih untuk segera pensiun. Hasil penelitian ini mendukung penelitian sebelumnya yang dilakukan oleh Desmette dan Gaillard, 2008.

16. Hipotesis 6 yaitu "Karakteristik pekerjaan berpengaruh positif pada kejenuhan". Nilai C.R karakteristik pekerjaan pada kejenuhan adalah sebesar 3,268, dengan tingkat signifikansi $\mathrm{p}<0,05$, maka menunjukkan bahwa hipotesis 6 didukung. Artinya secara statistik dapat disimpulkan bahwa dalam penelitian ini semakin pegawai senior meras tertantang dan diberikan peluang dalam pekerjaan maka mereka merasa semakin jenuh dengan pekerjaan. Pegawai senior sudah bekerja dalam waktu yang lama, sehingga mereka cenderung menginginkan pekerjaan yang sesuai dengan usianya, ketika tantangan dan peluang dirasa memberatkan maka akan muncul kejenuhan yang dapat mempengaruhi perilaku mereka dalam pekerjaan. Hasil penelitian ini mendukung penelitian sebelumnya yang dilakukan oleh Henkens dan Leenders, 2010.

17. Hipotesis 7 yaitu "Dukungan sosial berpengaruh negatif pada kejenuhan". Nilai C.R dukungan sosial pada kejenuhan adalah sebesar $-5,598$, dengan tingkat signifikansi $p<0,05$, maka menunjukkan bahwa hipotesis 7 didukung. Artinya secara statistik dapat disimpulkan bahwa dalam penelitian ini semakin besar dukungan sosial yang didapat pegawai senior, maka kejenuhan dalam pekerjaan semakin mudah dihindari. Dukungan sosial dari atasan, rekan kerja, kolega dan lain-lain membuat pegawai senior nyaman dalam lingkungan kerjanya, sehingga mereka akan menikmati pekerjaan yang dijalaninya dan tidak akan merasa jenuh. Hasil penelitian ini mendukung penelitian sebelumnya yang dilakukan oleh Henkens dan Leenders, 2010.

18. Hipotesis 8 yaitu "Kejenuhan berpengaruh positif pada keinginan untuk segera pensiun". Nilai C.R kejenuhan berpengaruh pada keinginan untuk segera pensiun adalah sebesar 3,034 , dengan tingkat signifikansi $p<0,05$, maka menunjukkan bahwa hipotesis 8 didukung. Artinya secara statistik dapat disimpulkan bahwa dalam penelitian ini semakin pegawai senior merasa jenuh dengan pekerjannya, maka semakin tinggi keinginan mereka untuk segara pensiun.

\section{SMPULAN}

Simpulan dari penelitian ini adalah sebagai berikut:

1. Identifikasi pegawai senior berpengaruh positif pada persaingan antar generasi dan redefinisi usia, dan berpengaruh negative ada pengembangan karir, transisi pegawai ke pensiun, devaluasi pekerjaan dan keinginan untuk segera pensiun.

2. Kesediaan untuk tidak mengelompok berpengaruh positif pada keinginan untuk segera pensiun dan tidak berpengaruh pada pengembangan karir, persaingan antar generasi dan redefinisi usia, transisi pegawai ke pensiun dan devaluasi pekerjaan. 
3. Karakteristik pekerjaan berpengaruh positif pada pengembangan karir, persaingan antar generasi dan redefinisi usia, transisi pegawai ke pensiun, devaluasi pekerjaan, kejenuhan dan keinginan untuk segera pensiun.

4. Dukungan sosial berpengaruh negative pada kejenuhan dan kejernuhan berpengaruh positif pada keinginan untuk segera pensiun.

5. Hasil analisis data menunjukkan bahwa ada pengaruh langsung dan tidak langsung antara karakteristik pekerjaan pada keinginan untuk segera pensiun. Pengaruh langsung lebih besar dari pada pengaruh tidak langsungnya. Kejenuhan memediasi pengaruh tidak langsungnya.

6. Dari hasil penelitian ini dapat dinyatakan bahwa pegawai senior di lingkungan Kementerian Komunikasi dan Informatika Jakarta merasa memiliki kekhawatiran tentang pensiun dan mengalami kejenuhan dalam pekerjaan.

\section{Rekomendasi}

1. Pegawai senior dilingkungan Kementerian Komunikasi dan Informatika Jakarta perlu untuk mendapat perhatian terkait adanya kekhawatiran tentang pensiun dan kejenuhan pada pekerjaan. Bentuk perhatian dapat berupa pemberian pekerjaan yang sesuai dengan usia dan kapabilitas pegawai senior, dukungan sosial dari lingkungan pekerjaan, perlakuan dan kesempatan yang sama antara pegawai senior dan pegawai muda, adanya kegiatan yang melibatkan semua pegawai baik senior maupun muda untuk mempererat hubungan sosial antar generasi, serta tetap memberikan pendidikan dan pelatihan sesuai bidang kerja untuk meningkatkan kinerja.

2. Pegawai senior perlu mendapat perlakuan yang sama dengan pegawai muda dari sisi kesempatan dan peluang dalam karir dan pekerjaan untuk mengurangi adanya diskriminasi dan persaingan antar generasi di tempat kerja.

3. Pegawai senior perlu mendapatkan informasi yang cukup tentang pensiun untuk menambah kesiapan dan mengurangi kekhawatiran pegawai senior tentang pensiun. Bentuk pemberian informasi dapat berupa kegiatan bimbingan teknis tentang prosedur pengajuan pensiun, pembekalan pegawai menjelang pensiun dan dibentuk organisasi kesatuan pensiunan pegawai.

4. Berdasarkan hasil penelitian ini, variabel kesediaan untuk tidak mengelompok tidak berpengaruh pada pengembangan karir, persaingan antar generasi dan redefinisi usia, transisi pegawai ke pensiun dan devaluasi pekerjaan. Hasil tersebut berbeda dengan hasil penelitian sebelumnya yang dilakukan pada pegawai perusahaan swasta. Hal ini terjadi karena perbedaan budaya dan kebijakan antara perusahaan swasta dan instansi pemerintah. Untuk itu penelitian selanjutnya sebaiknya dilakukan pada beberapa organisasi yang memiliki budaya dan kebijakan yang berbeda.

5. Penelitian selanjutnya sebaiknya tetap menggunakan variable-variabel seperti dalam penelitian ini, namun perlu ditambahkan variabel karakteristik personal. Sebab karakteristik personal berperan dalam persepsi, pembentukan sikap pegawai pada pekerjaan dan pensiun.

6. Penelitian selanjutnya sebaiknya menguji pengaruh variabel karakteristik pekerjaan pada keinginan untuk segera pensiun dengan variabel kejenuhan sebagai variabel mediasi. 


\section{DAFTAR PUSTAKA}

Buyens, Dirk. Dijk, Hans van. Dewilde, Thomas. And Vos, Ans De. 2009. The aging workforce: perceptions of career ending, Journal of Managerial Psychology, Vol.24.(2),pp.102-117.

Desmette, Donatienne. and Gaillard, Mathiu. 2008. When a "worker" becomes an "older worker, Journal of Career Development International,Vol.13.(2), pp.168-185

Ghozali, Imam., dan Fuad. 2005. Structural Equation Modeling ; Teori, Konsep \& Aplikasi Dengan Program Lisrel 8.54, Semarang, Badan Penerbit Universitas Diponegoro.

Henkens, K.1999, Retirement intentions and spousal support: a multi-actor approach, Journal of Gerontology: Social Sciences, Vol. 54B, pp. S63-S73
Henkens, Kene. and Leenders, Monique. 2010. Kejenuhan and older workers intention to retire, International Journal of Manpower, Vol.31.(3),pp.306-321.

Maslach, C. and Jackson, S.E. 1981, The measurement of experienced kejenuhan, Journal of Occupational Behaviour, Vol. 2. No. 2, pp.99-113

Mummenday, A.,Kessler, T.,A. and Mielke, R.1999, Strategies to cope with negative social identity: predictions by social identity theory and relative deprivation theory, Journal of Personality and Social Psychology, Vol.76.No. 2, pp. 229-45

Schaufeli, W. and Van Dierendock, D. 2000, Utrechtse Schaal, Handleiding, Swets \& Zeitlinger B.V., Liese

Shirom, A. 2003, Handbook of occupational Health Psychology, American Psychological Associatio 